\title{
HAART and response to therapy improve quality of life (QOL) of African patients with advanced HIV-associated Kaposi's sarcoma (HIV-KS): a prospective analysis of $\mathrm{QOL}$ in the KAART trial
}

\author{
Anisa Mosam ${ }^{1 *}$, F Shaik ${ }^{1,2}$, T Uldrick ${ }^{2,3}$, T Esterhuizen ${ }^{1}$, G Friedland ${ }^{4}$, D Scadden ${ }^{5}$, J Aboobaker ${ }^{1}$, H Coovadia ${ }^{1,6}$ \\ From $12^{\text {th }}$ International Conference on Malignancies in AIDS and Other Acquired Immunodeficiencies \\ (ICMAOI)
}

Bethesda, MD, USA. 26-27 April, 2010

\section{Background}

Quality of Life (QOL) assessment is important in oncology studies. Effect of therapy on QOL is important in HIV-KS, as decreasing morbidity is a goal of therapy. This is the first prospective study to evaluate the effect of HAART, +/- chemotherapy, on QOL in African patients with HIV-KS. Within the KAART study, we assessed the impact of HAART over 12 months in all patients, differences in QOL between arms, as well as associations between QOL and several clinical parameters.

\section{Methods}

KAART is a randomized, controlled, open label trial of HAART vs. HAART plus chemotherapy (CXT) in treatment-naive South African patients with HIV-KS. QOL outcomes were assessed prospectively in English or isiZulu using EORTC-QOL30. We evaluated intra-group changes between baseline and month 12 QOL scores (Wilcoxon rank sign test), changes between baseline and month 12 QOL scores between the two groups (Mann-Whitney test), and the relationship between clinical responses and global QOL (Kruskal-Wallis test). Given multiple comparisons, $\mathrm{p}$-values $<0.01$ are considered statistically significant; $0.01<\mathrm{p}<0.05$ represent important trends.

\section{Results}

111 participants had QOL information. Median global health score (perfect score $=100$ ) was 50 at baseline,

\footnotetext{
*Correspondence: mosama@ukzn.ac.za

'University of KwaZulu Natal, Durban, South Africa

Full list of author information is available at the end of the article
}

improving to 67 at month $12(\mathrm{p}<0.001)$. Significant improvements in median scores from baseline to month 12 were seen in emotional, cognitive, and social scales, but not physical function and role function. Most symptom scales (fatigue, pain, dyspnea, insomnia, appetite, diarrhea, and constipation) showed significant improvement over time. Improvement in nausea was borderline $(\mathrm{p}=0.03)$. There were no statistically significant changes over time between arms; however role function $(\mathrm{p}=0.011)$ trended toward greater improvement in the CXT arm. Complete or partial response was associated with increased global health scores $(\mathrm{p}<0.001)$, while number or severity of adverse events, adherence, HIV viral load, or CD4 count were not.

\section{Conclusion}

African HIV-KS patients benefit significantly in their overall global health status, functioning and symptoms from HAART. Partial and complete responses to therapy are significant predictors of global health, and the role of early chemotherapy in advanced HIV-KS merits further investigation. Improving QOL is an important goal in the treatment of advanced KS in resource-limited settings. QOL results from this study inform treatment paradigms for management of African patients with HIV-KS.

\footnotetext{
Acknowledgements

This article has been published as part of Infectious Agents and Cancer Volume 5 Supplement 1, 2010: Proceedings of the $12^{\text {th }}$ International Conference on Malignancies in AIDS and Other Acquired

Immunodeficiencies (ICMAOI). The full contents of the supplement are available online at http://www.biomedcentral.com/1750-9378/5?issue=S1.
} 


\section{Author details}

${ }^{1}$ University of KwaZulu Natal, Durban, South Africa. ${ }^{2}$ CAPRISA and SA-

Columbia Fogarty AITRP. ${ }^{3}$ Columbia University, New York, NY, USA. ${ }^{4}$ Yale University School of Medicine, New Haven, CT, USA. ${ }^{5}$ Harvard Medical School, Boston, MA, USA. ${ }^{6}$ Reproductive Health and HIV Research Unit, University of the Witwatersrand, Johannesburg, South Africa.

Published: 11 October 2010

doi:10.1186/1750-9378-5-S1-A30

Cite this article as: Mosam et al:: HAART and response to therapy improve quality of life (QOL) of African patients with advanced HIVassociated Kaposi's sarcoma (HIV-KS): a prospective analysis of QOL in the KAART trial. Infectious Agents and Cancer 2010 5(Suppl 1):A30,

Submit your next manuscript to BioMed Central and take full advantage of:

- Convenient online submission

- Thorough peer review

- No space constraints or color figure charges

- Immediate publication on acceptance

- Inclusion in PubMed, CAS, Scopus and Google Scholar

- Research which is freely available for redistribution

Submit your manuscript at www.biomedcentral.com/submit
C Biomed Central 